\title{
Discussion on the General Level of Present Domestic Market Price and Countermeasures in China
}

\author{
Xiantao Zhang* \\ Sichuan University \\ Chengdu, China
}

\author{
Shiwei Liu \\ Sichuan University \\ Chengdu, China
}

\begin{abstract}
Price is a reflection of value, and is also an orientation of economic activities which the people undertake under the condition of commodity economy. The reasonable price determines whether economics can work well, it is the general reflection of economic operating situation of China and it provides an important evidence for price of commodities control. Although the present price of commodities is moderate and controllable, along with the general positive tendency of economic operating situation of China, the price reform of some key sectors still needs proceeding.
\end{abstract}

Keywords-market price; general level; CPI; PPI

\section{INTRODUCTION}

Price is the key factor of market mechanism, and a reasonable price level is of importance to optimize resources allocation and accelerate economic development. Since reform and opening-up in 1978, China has witnessed a great development in price management system reform, the general price level changes can overall reflect changes in market demand and supply as well as commodity value, and the price level generally lies in a reasonable section. Influenced by national economic environment, although China's price level is still controllable, it also possesses some kinds of new traits, the price mechanism reform confronts a new challenge. Due to this, the paper, on a basis of definition of the contents of price general level, analyzed the basic status of national price on general level, and put forward policy proposals of optimizing china's price mechanism in accordance to the specific issues on the general level of price in China in order to better promote the further reform and development of economic system reform in China.

\section{THE RELEVANT CONCEPTS DEFINITION ABOUT THE GENERAL LEVEL OF PRICE}

The general level of price is a reflection of a series of price index. Zhuoyuan Zhang (1987) pointed out that the statistics of commodity price is composed of national general retail price index, the worker price total cost of living index, the general index of purchasing price of farm products, and the total retail price index of rural industrial products ${ }^{[1]}$. And the general level of commodity price generally means the general level of commodity market price which are always demonstrated by national general retail price index, and sometimes by the worker price total cost of living index ${ }^{[2]}$.
Guangjian $\mathrm{Xu}$ (2003) held an opinion that due to the long-run mixed-use of the general level of price and the general level of commodity price, The People's Republic of China National Economic and Social Development five-year Plan and Vision Programs in 2010, which was approved by the fourth meeting of the National People's Congress in March, 1996, clearly took the overall price level as one of the goals of the macroeconomic regulations and controls. The price law of the People's Republic of China approved by Standing Committee of the National People's Congress in December 1997 even listed the general price level control as a special chapter for a purpose of regulating the special significance and means of controlling the general level of price. Hence, "it is a normative and widely-used economic concept, but the concepts like commodity price and the general level of commodity price are rare used gradually." "[3]

In regard to the relevant concepts of the general price level, academic expression differed. Rongzhang Qiao (1988) insisted that the general price level is the average level of all kinds of commodity price in a certain period ${ }^{4]}$. Based on Qiao's theory, Guoguang Liu (1990) further pointed out that the overall price level is the average status, or comprehensive reflection of the changing degree in all kinds of commodity prices during a given period ${ }^{[\mathbf{5}]}$. Xiuyan Jia (1990) indicated that the general price level is a dynamic combination of all social commodity prices, and it is the weighted average level illustrated by the total index performance for all kinds of commodity price index. ${ }^{[6]}$ Changnuan $\mathrm{Hu}$ (1991) deemed that the general price level is refers to the weighted average level of total index of all kinds of commodity price of national economy ${ }^{[7]}$. Manping $\mathrm{Lu}$ (1998) possessed an opinion that the price level is the comprehensive reflection of all social price movements, and it is the comprehensive weighted average of all the prices of goods and services and factors of the whole society in a certain period of time. ${ }^{[8]}$ Peiyan Zeng (2002) insisted that the overall price level is also called the general price level, and it means an average or comprehensive status of all kinds of commodity and service price changing tendency in an entire society of a country (or region) during a given period ${ }^{[9]}$. The overseas scholars like Mishkin (1998) deemed that the general price should be defined as the average prices indicators of economy and society ${ }^{[10]}$.

*Corresponding author, School of economics, Sichuan University, 


\section{QUESTIONS OF THE GENERAL PRICE LEVEL NEED DISCUSSING}

\section{A. Questions about the Scope of the Overall Price Level}

In the book of new market price, Guifang Wen pointed out that the meaning of price of commodity can be divided into 2 halves; Namely, the general commodity prices and special commodity prices. And the general commodity prices include there aspects: item commodity prices, service commodity prices and elements commodity prices. The special commodity prices refer to the commodity prices when the general price minus the service and elements commodity prices, and in general, it refers to the price of subsistence means ${ }^{[11]}$.

\section{B. Relationship between the General Price and Price Index}

Guangjian $\mathrm{Xu}$ (2003) put forward an idea that the general price level exists objectively, but the price index is a measuring tool to reflect the general price level ${ }^{[12]}$. Guifang Wen (1999) insisted that the total index of price only reflects the difference of general price level between two different periods, or is a comparatively index reflecting the variety degree, and it did not equals the general price level. In general, the total price index and the price total level are two different concepts, they link and differ, and both of them can not be confused ${ }^{[13]}$.

\section{The Meaning of Level or Total Level of the Price General Level}

Price level means price changing degree, and general level is average or weighted average of every price changing degree. Guangjian Xu (2003) also concluded the precise meaning of the general price level which is comprehensive or weighted average of all sorts of degree of changes in prices of goods or services in a country or region in a certain period. As for the term, $\mathrm{Xu}$ emphasized a lot hereinafter: First of all, the general price level is a total price level of one country or region; it closely links to the space concept of a country or region. Generally, the space scope always falls onto a country or region where the same currency is used. Secondly, the general price level is a total level including all kinds of commodities or services in the entire society. Thirdly, the general price level is average composite reflecting varying change degree of all commodities or service prices between two points or in a period. Therefore, the general price level has both meaning of comparison and average. Comparison is the price comparison between two points in time, also is comparison of average price or absolute value of two-point intervals in time. Average is weighted average of changing degree of all commodities or service prices, also is the average of each relative number. Fourthly, the price general level is a macro-economic concept and is a concept concerning China's economic growth $^{[14]}$.

\section{Statistical Method about the General Price Level}

The consumer price index (CPI) uses sampling methods to select survey spots, following the principle of "fixed people, fixed place, fixed time", directly assigning people to collect original price at the survey spots. These data come from more than 63 thousand survey spots at 500 counties in 31 provinces, including grocery stores, department stores, supermarkets, convenience stores, professional markets, specialty shops, shopping centers, agricultural markets and service consumption units. Industrial producer price survey combines the survey method of the key investigation and the typical investigation. The enterprises with the annual income of more than 20 million Yuan use the key survey methods; the enterprises with the annual income of less than 20 million Yuan use the typical survey method. Industrial producer price survey involves nearly 60 thousand industrial enterprises in more than 400 cities of china. Industry classification standard is based on the National Economical Industry Classification (GB/T4754-2011) ${ }^{[15]}$.

\section{E. The Statistical Indicators of General Level of Market Price}

The main statistical indicators of price in China contain the industrial producer price index, the CPI, the RPI, the stock price index, etc. The industrial producer price index includes the industrial producer ex-factory price index and industrial producer purchase price index. Industrial producer ex-factory price index reflects the change trend and the change range of the ex-factory price of the industrial enterprise product at the first sale. Industrial producer purchase price index reflects the change trend and the change range of the purchase price of the industrial enterprise as the intermediate input product. CPI, the consumer price index, is "a relative number reflecting the changes of the price of domestic goods and the price of service purchased by urban and rural residents in a certain period. Through it can observe the change level of the consumer prices and its impact on the consumers' spending, and it can also reflect the degree of inflation." CPI "is a relative number measuring the price level of consumer goods and services of residents which changes with the time, reflecting the changes of the price level of the consumer goods and services purchased by residents." RPI, the retail price index, is a kind of economic index that reflects the change trend and degree of retail price in urban and rural areas." "It includes three levels of data: the national, the urban and the rural one, and the classification index of the retail price of goods on a monthly basis and year on year basis." Stock price index is "the comparison between the total price of the sample stock calculation period and the total price of the selected stock at the base period, reflecting the changes of the price level in each period, briefly referred to as the stock price index. The index unit commonly uses "point", "point" is the scale to measure the ups and downs of the stock price, which means that taking 100 as the base index, each increase or decrease of one percentage point is called "1 points"." Consumer price index and retail price index both belong to the price index, and there is no essential difference in the method of preparation, but they reflect two different areas, and their prepare purposes are different. The consumer price index is the one in the consumption field, from which can observe the impact of the price change of consumer goods and services upon the residents, and provide the scientific basis for levels of government to handle the resident consumption status, research and make the 
consumer price policy and salary policy. The retail price index belongs to the circulation field, from which can grasp the average price level of the retail commodity, and provide scientific basis for the levels of government to constitute economic policy and research the market circulation ${ }^{[16]}$.

\section{The Control Measures of THE General LEVEL OF MARKET PRICE}

The general level of market price reflects the overall situation of the price of an economy in a specific period. It is not only a comprehensive reflection of the economic performance, but also provides an important basis for the formulation of economic policies and the regulation of prices, and it also has a significant impact on people's economic expectations.

From the current price level reflected by the CPI and PPI, the overall price of China is in a moderately controllable state, the overall economic fundamentals is good, but the price reforms of some important areas still need to be further advanced.

- Further push the price reform of resource products. The price reform of resource product needs to further clarify the ownership of resources, establish the price formation mechanism which reflects the scarcity of resources and the costs of environmental damage, and promote the compensable development and utilization of resources, making the resource prices could both reflect the extent of resource scarcity and ensure the need of reasonable consumption of all levels. And compel enterprises reduce the use of energy as well as raw material, improving economic effectiveness and utilization efficiency of resources.

- Push the target price pilot of agricultural products. The target price pilot of major agricultural products like cotton and soybeans should be promoted, the price formation mechanism that the agricultural prices and government subsidies are decoupling should be established, effectively improving the income of peasants and ensuring the national food security. The specific measures are listed hereinafter: (1) The target price institutions must be specified and what the key is to handle the relationship between the market and government in course of agricultural products price formation, and to set the institution target in compensating the imperfection of agricultural product price policies, building up mechanism of agricultural product price decided by market, putting the governmental responsibilities under the limited governmental functions, and improving the scientificity, veracity and predictability of controlling agricultural product price. (2) The reasonable price level has to be ascertained. The core foundation of building up agricultural product target price is not only to ensure the farmers' benefits, promoting the robust development of agriculture and optimizing the planting structure of agricultural product and protecting environment, but also to fully consider the government financial capacity and then keep the target price lower to reduce the government financial burden in a purpose of reflecting the need and supply of agricultural product market and relations with the international market price. (3) Prudent positive reform strategies must be insisted. Building up the system of agricultural products target price is a major change in the price mechanism of agricultural products, which covers the interests of peasants and consumers, the development of agriculture and the steadiness of country as well as government finance. Hence, prudent positive reform strategies must be adopted. Initially, the key pilot strategies need adopting and then regional and phased strategies need implementing.

- Push the price reform of monopoly industries. The boundary between government and market should be clarified, the institutional mechanisms should be improved, the competition mechanism should be introduced, breaking the monopoly, banning regional monopoly, establishing an open and transparent access mechanism of monopoly market, and steadily promoting the price reform of monopoly industries. The main methods are listed below: The first step is to timely probe consumers opinion on the price of monopoly industries for changing price at an appropriate time. The second step is to build all kinds of information platform to solicit opinions from the social from all walks of life when the monopoly industry operators apply for changing price in order to make decision give full consideration to the bearing capabilities of people and the related companies. The third step is to employ expertise and scholars in participating the government price decision, making price decision more rational.

- Further improve the price formation mechanism of major products. Follow the law of value, improve the circulation system, perfect the market mechanism, continue to push the price reform of coal, electricity, petrol, transportation and major agricultural commodities, trying to form the price mechanism that enterprises could independently price, government could make macro regulation and market could make multiple choices.

\section{CONCLUSION}

The paper initially clarified the contents of price general level and analyzed the key questions of the scope of the overall price Level, the relationship between the general price and price index, the meaning of level or total Level of the price general level, the statistical method of the general price level, and the statistical indicators of general level of market price individually so as to lay a theoretical foundation for national price reform and control. And then, pinpointing those issues in the above-mentioned sectors, the paper further put forward countermeasures of the general level of market price in hereinafter 4 aspects: further pushing reform on resources price, pushing the target price pilot of agricultural products, pushing the price reform of monopoly industries, and improving the price formation mechanism of 
major products. The paper held an opinion that although national price level is still controllable, the influencing factors of price change are complicated. Therefore, the formation mechanism of major products need further improving, supply-side structural reform needs pushing, and the quality of products need improving to satisfy market demand. In the end, the paper suggested making price signals play an important role in optimizing the allocation of resources, promoting the balance between supply and demand, and accelerating the economic development.

\section{REFERENCES}

[1] Zhuoyuan Zhang. The Socialism Price Theory and Price Reform. Beijing: China Social science press, 1987.p.187.

[2] Zhuoyuan Zhang. The Socialism Price Theory and Price Reform. Beijing: China Social science press, 1987.p.187.

[3] Guangjian Xu. Study on Price Total Level Control.Beijing: China Prices Press, 2003.pp:5-6.

[4] Rongzhang Qiao. Price Management Dictionary. Beijing: China Prices Press, 1988.pp:613.

[5] Guoguang Liu. The Dictionary of Economics--Volume of Planning. Shanghai: Shanghai Lexicographical Publishing House, 1990,P.395.

[6] Xiuyan Jia.Price Theory.Tianjin:Nan University Press, 1990, P.336.

[7] Changnuan Hu. Theory.Beijing:China Renmin University Press, 1991, P.284.

[8] Manping Lu. The Micro Endogenous Mechanism of the Increased Price Level. China Prices Press, 1999.p.1.

[9] Peiyan Zeng. Macroeconomic Booklets Leading Cadres.Beijing: People's Publishing House, 2002,P.67.

[10] Mishkin.Monetary finance. (4th edition) Beijing: China Renmin University Press, 1998,P.17.

[11] Guifang Wen. The New Market Price.Beijing: Economic Science Press, 1999, P.163.

[12] Guangjian Xu. Study on Price Total Level Control.Beijing: China Prices Press, 2003.p.8

[13] Guifang Wen. The New Market Price.Beijing: Economic Science Press, 1999, P.163.

[14] Guangjian Xu. Study on Price Total Level Control.Beijing: China Prices Press, 2003.pp:11-13.

[15] Bureau of China Statistics website:http://data.stats.gov.cn/workspace/index?m=hgyd

[16] Yuhua Guan. Statistics.Beijing:Higher Education Press, 2013:432343. 